University of Nebraska - Lincoln

DigitalCommons@University of Nebraska - Lincoln

Faculty Publications: Department of Entomology

1981

\title{
Ovicidal Activity of Insecticides against Planthoppers on Rice
}

\author{
E. A. Heinrichs
}

S. L. Valencia

Follow this and additional works at: https://digitalcommons.unl.edu/entomologyfacpub

Part of the Agriculture Commons, and the Entomology Commons

This Article is brought to you for free and open access by the Entomology, Department of at

DigitalCommons@University of Nebraska - Lincoln. It has been accepted for inclusion in Faculty Publications:

Department of Entomology by an authorized administrator of DigitalCommons@University of Nebraska - Lincoln. 
Published in Journal of Economic Entomology 74:1 (1981), pp. 49-53; doi: 10.1093/jee/74.1.49

Copyright $\odot 1981$ Entomological Society of America. Published by Oxford University Press. Used by permission.

Submitted April 4, 1980.

\title{
Ovicidal Activity of Insecticides against Planthoppers ${ }^{1}$ on Rice
}

\author{
E. A. Heinrichs and S. L. Valencia
}

The International Rice Research Institute, Manila, Philippines

\begin{abstract}
Insecticides were evaluated to determine their ovicidal activity against rice-feeding planthoppers, Nilaparvata lugens (Stål) and Sogatella furcifera Horvath. Carbofuran, methyl parathion, and triazophos were ovicidal as foliar sprays, and carbofuran, diazinon, metalkamate, and triazophos were ovicidal as paddy-water applications of granules in insectary studies. In a field study, only triazophos as a foliar spray provided significant ovicidal activity against $N$. lugens. Eggs of $S$. furcifera were more susceptible to insecticides than those of $N$. lugens. Ovicidal activity was dependent on age of egg at the time of insecticide application and on insecticide concentration.
\end{abstract}

Nilaparvata lugens (Stål) has been an important rice pest in China, Japan, and Korea for many years but has only recently become a serious pest throughout tropical Asia (Dyck 1979). In addition to causing direct damage which can result in the complete drying of the plants, a condition known as "hopper burn" (Bae and Pathak 1970), N. lugens transmits grassy stunt disease and ragged stunt virus (Ling et al. 1978) and has recently been found to transmit wilted stunt virus (Chen et al. 1978). Resistant varieties have been released, but their success has been limited by the selection for N. lugens biotypes (Khush 1977). Another planthopper, Sogatella furcifera Horvath, a pest for which no resistant variety has been released, has been reported to be increasing in severity in several Asian countries. Because of these factors, insecticides are still commonly used for planthopper control in rice production.

Because planthopper eggs are laid within the leaf sheath tissue at the base of the plant, they are somewhat protected from insecticides. The hatching of nymphs a few days after a short residual insecticide is applied can result in higher populations than before spraying. 
To decrease the number of insecticide applications which are necessary under outbreak conditions it is necessary to identify insecticides that combine ovicidal activity with control of nymphs and adults.

Studies have been conducted in Japan and the Philippines to identify insecticides with an ovicidal effect on N. lugens eggs (Toyoda 1968, Ito and Saito 1973, Preedasuvan and Pura 1973, and Nagata and Moriya 1975). Nagata and Moriya (1975) found chlordimeform to be ovicidal when seedling roots were dipped in a $10 \mathrm{ppm}$ solution. Ito and Saito (1973), also using a rootdip technique, found parathion to be the most toxic of several insecticides tested. Toyoda (1968) compared the ovicidal activity of granular formulations of carbamate, organochlorine, and phosphate insecticides when applied to the paddy water in pot experiments. The carbamates, propoxur and MIPC, were ovicidal while the phosphate diazinon and the organochlorine lindane were not. According to Moriya (1977) most carbamates have some ovicidal effect against $N$. lugens.

In India, Israel et al. (1968) compared the relative susceptibility of $N$. lugens and S. furcifera eggs to sprays of carbaryl, diazinon, endosulfan, endrin, and parathion. Only carbaryl and parathion had some degree of ovicidal activity against $S$. furcifera while none were active against $N$. lugens.

Because of the continuing threat of planthoppers throughout Asia and the difficulty in achieving effective chemical control, additional insecticides were evaluated to determine their ovicidal activity when applied as foliar sprays against $N$. lugens and S. furcifera and as granules against $N$. lugens.

\section{Materials and Methods}

The planthoppers were mass reared on an insect-susceptible rice variety "Taichung Native 1" (TN1). The original colonies were started by caging a pair of virus-free adults on a 50day-old potted plant. Insect-infested potted plants were maintained in cages.

TN1 plants used for oviposition were grown in wood flats in the greenhouse, and when seedlings were 25 days old they were transplanted in clay pots at one seedling/pot. Two days after transplanting, plastic oviposition cages $(4.5 \mathrm{~cm}$ high and $4.5 \mathrm{~cm}$ diam) with a fine mesh nylon screen wall at one side were installed at the basal portion of the plant and supported with a wooden pot label. Two gravid females were placed in each cage and allowed to oviposit for $24 \mathrm{~h}$. Insects and cages were then removed.

In the initial test, for each treatment, 4 potted plants containing one-day-old $N$. lugens eggs were placed on a revolving table and simultaneously sprayed with $25 \mathrm{ml}$ of a $0.04 \%$ solution using a bottle atomizer operating at a pressure of $0.7 \mathrm{~kg} / \mathrm{cm}^{2}$. The phosphate insecticides, dimethoate, methyl parathion, and triazophos, and the carbamates, BPMC, carbofuran, metalkamate, MIPC, and propoxur, were tested. The spray was directed toward the base of the plant where eggs were deposited. Plants sprayed with distilled water served as untreated controls. Treatments were replicated 4 times.

After treatment, plants were maintained at $27^{\circ} \pm 2^{\circ} \mathrm{C}$. A cylindrical mylar film cage, 10 $\mathrm{cm}$ diam and $55 \mathrm{~cm}$ in height, was installed over each plant. The number of hatching nymphs was recorded, and nymphs were removed daily for 14 days. After the last observation, plants were dissected and observed under a stereomicroscope to determine total 
number of eggs deposited. Eggs with no sign of development and completely developed eggs containing nonemerged nymphs were considered as unhatched eggs. Percent hatch was determined by dividing the total nymphs recovered by the total number of eggs deposited.

Based on the results of the 1st test, insecticides were selected for a 2 nd test, which was conducted to determine the comparative susceptibility of N. lugens and S. furcifera eggs to insecticides and the effect of egg age at time of spray application and concentration of spray solution on hatching of $N$. lugens and S. furcifera eggs. Insecticides tested were carbofuran, methyl parathion, and triazophos. Four concentrations (0.04, 0.02, 0.01, and 0.005\%) were sprayed on plants containing 1-, 3-, and 5-day-old eggs. Under conditions of this experiment, normal eggs hatched in 6 days. Plants were sprayed by the same technique as in the 1 st test.

In the 3rd test, the ovicidal activity of $\mathrm{G}$ formulations of carbofuran, diazinon, metalkamate, and triazophos against $N$. lugens was determined. Insecticides were applied at the rate of $1.0 \mathrm{~kg} \mathrm{AI} / \mathrm{ha}$ to the standing water of plants growing in porcelain pots. Eggs were one day old at time of application. Other procedures were identical as described for the previous spray tests.

Insecticides with ovicidal activity under controlled conditions were further tested in the field against $N$. lugens eggs. Seeds of the susceptible rice variety "IR22" were sown in a dry bed which was protected from insects, and seedlings were transplanted in the field 11 days after sowing. Immediately after transplanting, cylindrical mylar film cages were placed over 5 randomly selected plants in each plot. Fourteen days later, 5 laboratory-reared gravid females were placed in each cage, allowed to oviposit for $24 \mathrm{~h}$, and then removed. Cages were then removed and insecticides were applied. Carbofuran, metalkamate, and triazophos were each applied as a G broadcast treatment and a foliar spray at $1.0 \mathrm{~kg} \mathrm{AI} / \mathrm{ha}$, and each treatment was replicated 5 times. Granules were hand broadcasted and foliar sprays were applied to the canopy with a knapsack sprayer at a volume of 300 liters spray solution/ha. Immediately after insecticide application, cages were reinstalled over the plants. Eggs were 1-24 h old at the time of insecticide application. Water level was maintained at $2-3 \mathrm{~cm}$.

Emerging nymphs were counted and removed daily until hatching ceased. One week later, plants were removed from the field, taken to the laboratory, and dissected to determine the number of unhatched eggs.

\section{Results}

In the initial evaluation, 4 insecticides had an ovicidal effect when sprayed at a concentration of $0.04 \%$ on plants containing one-day-old N. lugens eggs (Table 1). Carbofuran had a strong ovicidal effect, with no eggs hatching. Dimethoate and methyl parathion had slight ovicidal activity while triazophos had moderate activity. 
Table 1. Ovicidal activity of insecticides applied as $0.04 \%$ foliar sprays on plants with one-day-old N. lugens, IRRI insectary, 1977

\begin{tabular}{lc}
\hline Insecticide & Egg hatch $^{\mathrm{a}}(\%)$ \\
\hline Metalkamate & $99 \mathrm{a}$ \\
Propoxur & $98 \mathrm{a}$ \\
BPMC & $90 \mathrm{ab}$ \\
MIPC & $88 \mathrm{ab}$ \\
Dimethoate & $83 \mathrm{~b}$ \\
Methyl parathion & $61 \mathrm{c}$ \\
Triazophos & $37 \mathrm{c}$ \\
Carbofuran & $0 \mathrm{~d}$ \\
Control & $96 \mathrm{a}$ \\
\hline a. All means within a column followed by a common letter \\
are not significantly different at the 5\% level by Duncan's \\
multiple range test.
\end{tabular}

In the 2nd test, the relative susceptibility of the eggs of the 2 planthopper species to the sprays of carbofuran, triazophos, and methyl parathion was dependent upon the concentration of the insecticide and age of eggs at time of spraying (Fig. 1). In all except one case, where there was a significant difference in egg hatching between the 2 species, the $S$. furcifera eggs had the lowest hatch. The species difference was most pronounced in 3-day-old eggs treated with methyl parathion where ovicidal activity was greatest against $S$. furcifera eggs at all concentrations.

For the one-day-old $N$. lugens eggs sprayed with a $0.01 \%$ concentration, triazophos and methyl parathion had the highest ovicidal activity (Fig. 1). However, carbofuran was more toxic than methyl parathion at all concentrations in the 5-day-old eggs. All concentrations of carbofuran had high ovicidal activity against the 5-day-old eggs. There was no significant difference in the hatchability on 3-and 5-day-old eggs of S. furcifera for any of the 3 insecticides, but the one-day-old eggs had significantly higher hatch than 3- and 5-day-old eggs at the $0.005 \%$ concentration. Hatch of 1-day-old carbofuran-treated $N$. lugens eggs ranged from $0 \%$ at the $0.04 \%$ concentration to $96.8 \%$ at the $0.005 \%$ concentration. Although all insecticides showed an increasing toxicity against older eggs, the degree of this increase was greater for carbofuran than for methyl parathion and triazophos. 


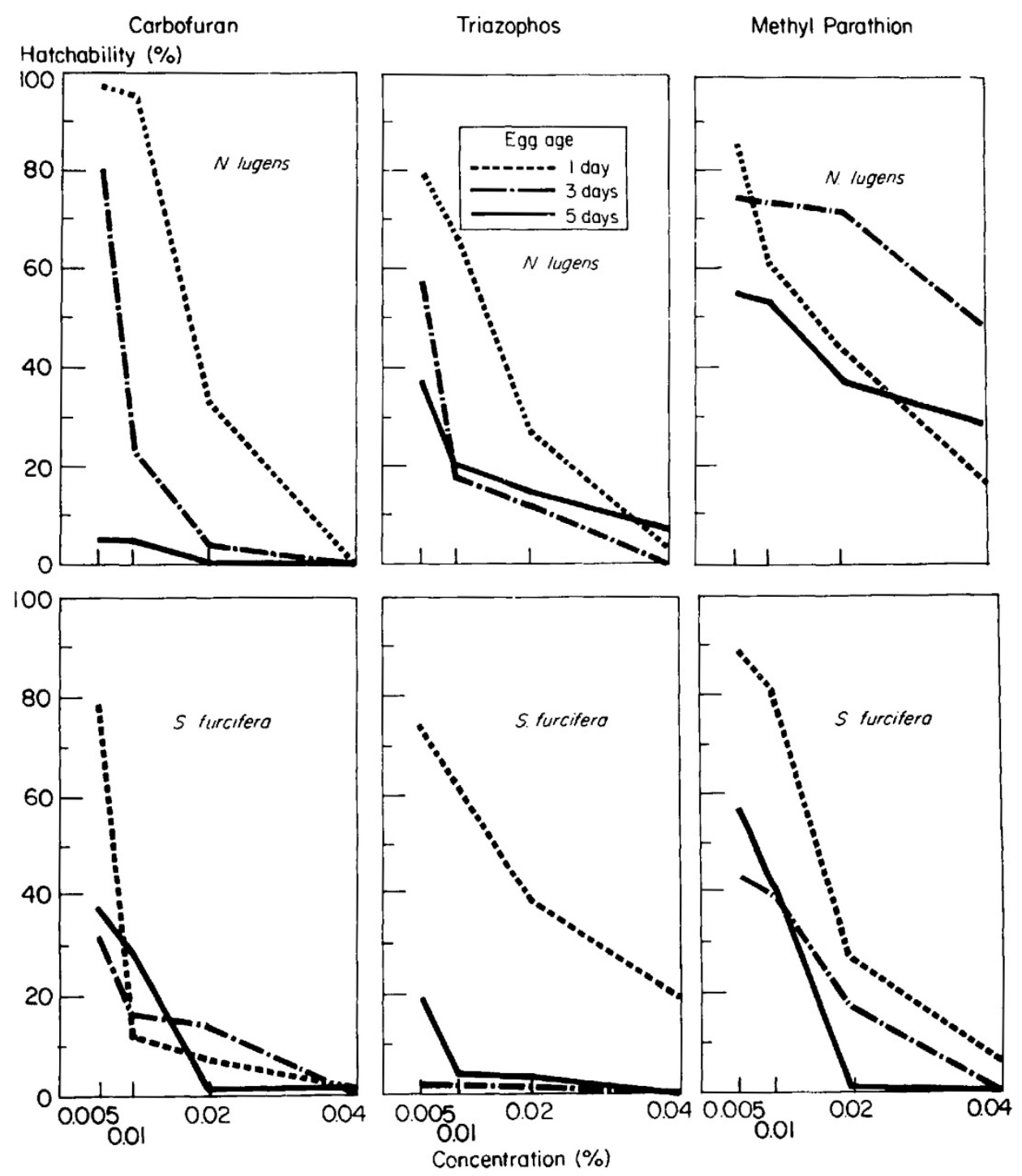

Figure 1. Ovicidal activity of carbofuran, triazophos, and methyl parathion when applied at 4 concentrations against 3 ages of $N$. lugens and S. furcifera eggs.

In the 3rd test, all insecticides applied as granules in the paddy water had ovicidal activity against $N$. lugens (Table 2). There was no hatch in the carbofuran, metalkamate, or triazophos treatments. 
Table 2. Ovicidal activity of granular insecticides applied to the paddy water of plants with one-dayold N. lugens eggs, IRRI insectary, 1977

\begin{tabular}{lc}
\hline Insecticides $^{\mathrm{a}}$ & Egg hatch (\%) \\
\hline Diazinon 10 G & $43 \mathrm{~b}$ \\
Carbofuran 3 G & $0 \mathrm{a}$ \\
Metalkamate 3 G & $0 \mathrm{a}$ \\
Triazophos 5 G & $0 \mathrm{a}$ \\
Control & $89 \mathrm{c}$ \\
\hline
\end{tabular}

a. Rate of insecticide $=1.0 \mathrm{~kg} \mathrm{AI} / \mathrm{ha}$. In a column, means followed by a common letter are not significantly different at the $5 \%$ level by Duncan's multiple range test.

In the field study, except for the triazophos foliar spray treatment, none of the insecticides applied as granules or foliar sprays exhibited ovicidal activity (Table 3).

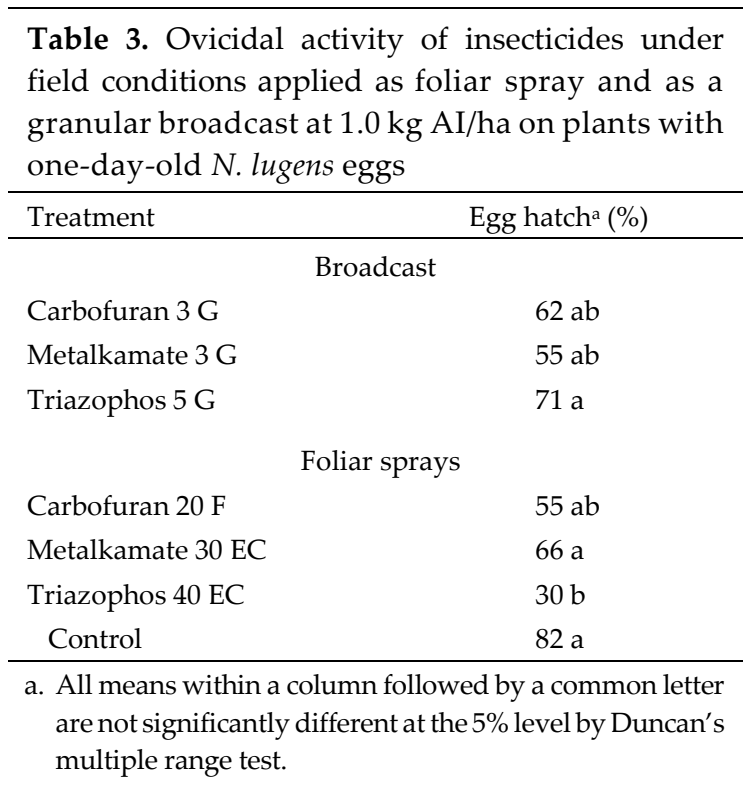

\section{Discussion}

Depending on concentration and egg age, $S$. furcifera eggs were generally more susceptible to the various insecticides than $N$. lugens eggs. S. furcifera adults were generally more susceptible to most insecticides than N. lugens adults (Anon. 1978). In insectary studies, carbofuran was highly active as an ovicide against $N$. lugens and $S$. furcifera both as a foliar spray and as a granule in the paddy water. Gunathilagaraj and Jayaraj (1977) found carbofuran to be ovicidal against a leafhopper Cicadella spectra (Distant) as a granular application to the paddy water at $2.0 \mathrm{~kg} \mathrm{AI} / \mathrm{ha}$.

Methyl parathion applied as a foliar spray had a moderate ovicidal effect against $N$. lugens and S. furcifera. It appeared to have a wide spectrum of ovicidal activity, as it has 
been reported as an ovicide against several species, including the peachtree borer, Synanthedon exitiosa (Say), Mexican bean beetle, Epilachna varivestris Mulsant, southern armyworm, Spodoptera eridania (Cramer) (O'Brien and Smith 1961), and a rice leafhopper, Nephotettix cincticeps Uhler (Toyoda 1968).

Although no direct comparisons were made, insectary studies indicated that both metalkamate and triazophos appeared to be more active when applied as granules in the paddy water as compared to their effectiveness as a foliar spray. Metalkamate had no activity as a spray (Table 1), whereas the paddy-water application completely prevented egg hatch (Table 2). A granular formulation of a systemic insecticide in the paddy water would be more effective as an ovicide than a foliar spray because of its systemic action through the roots, capillary action in the leaf sheath area (Pathak and Dyck 1973), and possible absorption directly through the stems (Bowling 1970).

Susceptibility of both hopper species was greatest in the older eggs. The N. lugens eggs were more susceptible on the 5th day after oviposition while the $S$. furcifera eggs were more susceptible on both the 3rd and 5th days than on the 1st day. According to Smith and Salkeld (1966), age of eggs affects susceptibility to insecticides, and this effect differs among species and insecticides.

One-day-old eggs treated with carbofuran completed embryonic development but did not hatch. Smith (1955) observed this phenomenon in peachtree borer eggs treated with parathion. In our study, embryos did not develop completely on plants treated with metalkamate and triazophos.

The reason that the paddy-water application of granules and the foliar sprays had poor ovicidal activity under field conditions was not determined. However, previous studies at IRRI have indicated that control of $N$. lugens adults is always much poorer under the environmental condition existing in the field as compared to controlled conditions in the airconditioned insectary. Poor field ovicidal activity of the sprays may have been partially due to poor coverage of plants. In the insectary study, entire plants were sprayed with a volume of spray solution equal to 1,040 liters/ha. Thus, the leaf sheath area at the base of the plant where eggs are deposited was thoroughly wetted. In the field, only the canopy was sprayed with a volume of 300 liters/ha which is the common practice of farmers. Thus, coverage of the plant base was not as thorough as in the insectary. There is only slight downward movement of carbofuran to the leaf sheaths (where the eggs are deposited) when it is sprayed on the upper leaf area (Seiber et al. 1978). Rainfall evidently was not the cause of poor ovicidal activity in the field as only $2 \mathrm{~mm}$ of rain fell prior to egg hatching.

The poor performance of granules in the field may have been due to rapid degradation. Studies with carbofuran as a granular treatment have shown that degradation is much more rapid in the field than under controlled conditions because of the diurnal fluctuations of paddy water $\mathrm{pH}$ (Siddaramappa et al. 1978).

Laboratory studies have shown that several insecticides have a high rate of ovicidal activity against planthoppers attacking rice. However, application methods and formulations may have to be modified to increase the ovicidal activity under field conditions to provide practical control against planthopper eggs in addition to the nymphs and adults. 


\section{Note}

\section{Homoptera: Delphacidae}

\section{References Cited}

Anonymous. 1978. p. 196. In International Rice Research Institute, Annu. Rep. 1977. 548 pp.

Bae, S. H., and M. D. Pathak. 1970. Life history of Nilaparvata lugens (Stål) (Homoptera: Delphacidae) and susceptibility of rice varieties to its attacks. Ann. Entomol. Soc. Am. 63: 149-55.

Bowling, C. C. 1970. Lateral movement, uptake, and retention of carbofuran applied to flooded rice plants. J. Econ. Entomol. 63: 239-42.

Chen, C. C., W. H. Ko, and R. J. Chiu. 1978. Rice wilted stunt and its transmission by the brown planthopper, Nilaparvata lugens (Stål). Plant Prot. Bull. Taiwan. 20: 376.

Dyck, V. A. 1979. The brown planthopper problem. pp. 3-17. In International Rice Research Institute, The Brown Planthopper: Threat to Rice Production in Asia. Los Baños, Philippines. 369 pp.

Gunathilagaraj, K., and S. Jayaraj. 1977. Ovicidal effects of some chemicals on the white rice leafhopper, Tettigella spectra Distant and red cotton bug, Dysdercus cingulatus Fabricius. Madras Agric. J. 64: 369-74.

Israel, P., M. B. Kalode, and B. C. Misra. 1968. Toxicity and duration of effectiveness of some insecticides against Sogatella furcifera (Horvath), Nilaparvata lugens (Stål), and Nephotettix impicticeps Ishihara on rice. Indian J. Agric. Sci. 38: 427-31.

Ito, T., and T. Saito. 1973. The ovicidal action of systemic insecticides on the eggs of Pieris rapae crueevora Boisduval and Nilaparvata lugens (Stål). (in Japanese) Jap. J. Appl. Entomol. Zool. 17: 41-42.

Khush, G. S. 1977. Disease and insect resistance in rice. Adv. Agron. 29: 265-341.

Ling, K. C., E. R. Tiongco, and V. M. Aguiero. 1978. Rice ragged stunt. A new virus disease. Plant Dis. Rep. 62: 701-5.

Moriya, S. 1977. Chemical control on rice planthoppers. pp. 148-61. In The rice brown planthopper. Proc. Sem. compiled by the Food and Fertilizer Technology Center for the Asian and Pacific Region, Taipei, Taiwan. 258 pp.

Nagata, T., and S. Moriya. 1975. Effect of chlordimeform on the brown planthopper Nilaparvata lugens (Stål). (in Japanese) Jap. J. Appl. Entomol. Zool. 19: 300-1.

O'Brien, R. D., and E. H. Smith. 1961. The uptake and metabolism of parathion by insect eggs. J. Econ. Entomol. 54: 187-91.

Pathak, M. D., and V. A. Dyck. 1973. Developing an integrated method of rice insect pest control. PANS (Pest Artie. News Summ.) 19: 534-44.

Preedasuvan, T., and C. D. Pura. 1973. Ovicidal effect of certain insecticides against the brown planthopper, Nilaparvata lugens (Stål). Araneta Res. J. 20: 295-317.

Seiber, J. N., E. A. Heinrichs, G. B. Aquino, S. L. Valencia, P. Andrade, Jr., and A. M. Argente. 1978. Residues of systemically applied carbofuran in irrigated lowland rice: implications for insect control. IRRI Res. Pap. Ser. No. 17: 28 pp.

Siddaramappa, R., A. C. Tirol, J. N. Seiber, E. A. Heinrichs, and I. Watanabe. 1978. The degradation of carbofuran in paddy water and flooded soil of untreated and retreated rice fields. J. Environ. Sci. Health 813: 369-80.

Smith, E. H. 1955. Further studies on the ovicidal action of parathion to the eggs of the peach tree borer. J. Econ. Entomol. 48: 727-31. 
HeInRICHS AND VALENCIA, JOURNAL OF ECONOMIC ENTOMOLOGY 74 (1981)

Smith, E. H., and E. H. Salkeld. 1966. The use and action of ovicides. Annu. Rev. Entomol. 11: 33168.

Toyoda, K. 1968. Studies on the effect of insecticide applied to the irrigation water on eggs of some rice insects. I. Effect of some kinds of insecticides on eggs of homopterous species. Proc. Assoc. Plant Prot. Kyushu 14: 21-25. 